\title{
The Effect of Company Size, Company Performance and Exposure to Media Exposure Availability of Environmental Information
}

\author{
Hamid Nazamuddin ${ }^{1,}$ Siti Suharni ${ }^{2,}$ Syarifah Ratih Kartika Sari ${ }^{3 *}$
}

\author{
1,2.3 Merdeka University of Madiun \\ *Corresponding author. Email:SYARIFAH@UNMER-MADIUN.AC.ID
}

\begin{abstract}
This objective of this research is to assess the influence of Company Size, Company Performance, and Media Exposure on the Availability of Environmental Information. The technique in sampling uses the purposive sampling method. The data was obtained from secondary data from 18 annual reports of manufacturing companies Food and Beverages subsectors listed on the Stock Exchange during 2016, 2017, and 2018. Data analysis was performed by multiple linear regression with SPSS version 16.00 for windows. The findings of the hypothesis analysis revealed that the independent variable of the company size was 0.983 . The independent variable of the company's performance was 0.588 , and the independent variable of the media exposure was 0.001 . With these results, it can be stated that company size and company performance have no significant effect, whereas media exposure has a significant impact.
\end{abstract}

Keywords: Company Size, Company Performance, Media Exposure

\section{INTRODUCTION}

Industrialization has penetrated Indonesia, and pollution is not only occurring in industrial estates but the population environment. This condition encourages the emergence of environmental regulations, such as Statement of Financial Accounting Standards (PSAK) No. 57, No. 1 paragraph 9, PSAK No. 32, [1] Statute of the Republic of Indonesia Number 25 of 2007 [2]. Globalization that occurs in the industrial environment results in companies must always meet the needs of user information. The company's demands create competition in the industrial world. A competitive corporate match must be balanced with critical thinking and effective utilization of company resources for companies to compete both domestically and abroad.

One of the most highlighted phenomena is the problem of waste pollution caused by large companies in the lack of management of the industry's remnants that is still minimal. For the community, this activity can trigger health problems and for stakeholders will reduce the attractiveness of the company because the company has violated the Industrial Law article 21 paragraph (1), which describes that "manufacturing industries must pay attention to the balance and preservation of the natural resources used in their industrial processes and to the avoidance of environmental degradation and contamination caused by the industry." In recent decades, companies have commonly practiced financial reporting to anticipate environmental issues to improve the principle of corporate prudence. Disclosure of environmental information is expected to be voluntary, and there is no standard so that the company is only used to accentuate its image.

\section{LITERATURE REVIEW}

\subsection{Stakeholder Theory}

Freeman first created stakeholder concept to explain company behavior and social performance [3]. The theory of stakeholders is a set of policies and practices relevant to stakeholders, principles, conformity with regulatory requirements, societal and environmental awards, and the determination of the business sector to contribute to sustainable growth. The theory of stakeholder claims that the stakeholders decide the existence of the company. 


\subsection{Legitimacy Theory}

Ghozali and Chariri [4] show the concept of legitimacy theory as a state or position that occurs because a company's value system is in accordance with the larger social value system that the company is a part of. The legitimacy theory is the foundation of the company's disclosure of environmental information because the theory of legitimacy is seen as a perspective orientation system, i.e. the company may influence it or be affected by the society in which the company works. The legitimacy of the company can be inferred as something that society brings to the company and something that the company needs or wants from the society.

\subsection{Hypothesis Development}

\subsubsection{Effect of Company Size on Environmental Disclosure}

Company size has a positive effect on the availability of environmental information because large companies will be required to have environmental responsibility [5]. Companies of greater sizes will appear to have a more important environmental impact by large companies, and companies will devote a great deal of concern both internally and externally to preserve the reputation of the company. The size of the company would have a significant effect on the environment that will draw the interest of the community. According to Dewi and Yasa [6], the size of the company is the scale that defines the size or size of a company. Large companies assessed with large levels of assets will reveal more environmental responsibilities carried out by the Company. The bigger the scale of the company, the greater the environmental impact. To maintain its legitimacy, the Company will make more disclosures as a responsibility to the community. The hypothesis is as follows:

$\mathrm{H} 1=$ The size of the Company has a positive effect on the Availability of Environmental Information.

\subsubsection{The effect of the company's performance on environmental disclosure.}

The performance of a company is the perception of the company's full state over a certain period and is the result of being influenced by the Company's operational activities. The Company will disclose more information when the Company's performance is good and vice versa when the Company's performance is not acceptable. The Company will find it challenging to perform environmental responsibilities. The company will disclose more information when the company's performance is good and vice versa when the company's performance is not good, the company will find it difficult to be able to carry out environmental responsibility [7]. According to Dewi and Yasa [6], the Company's performance is part of environmental performance, companies that have optimal performance in terms of the corporate environment tend to reveal environmental information. It can be stated that the hypothesis is:

$\mathrm{H} 2$ = Company performance has a positive effect on the Availability of Environmental Information.

\subsubsection{Effect of Media Exposure on Environmental}

Media exposure is a source of information, issues, promotions about activities and performance in a company through third party media such as the internet, newspapers, and other promotional media. For companies that want to gain trust and legitimacy through their environmental and social practices, the company must have the capacity to meet the community's needs and other parties such as stakeholders and shareholders. According to Aulia and Agustina [8], media exposure in this research represents the community and other stakeholders as nonshareholders. Nonshareholders rated the company's performance as based on media coverage issues compared to the company's financial side. The existence of media coverage shows that the public has information about the company's environmental issues. It makes the company react by creating a broader environmental disclosure to meet the needs of information for the community. The following is the hypothesis:

H3: Media exposure has a positive effect on environmental disclosure.

\section{RESEARCH METHOD}

\subsection{Data and Samples}

This study is including as a type of quantitative research. The data used in this analysis was secondary data in financial statements, annual reports, and data documentaries of other companies from [9]. This study's population amounted to 24 companies engaged in the Consumer Goods Industry sub-sector of food and beverages, the period 2016-2018 with purposive sampling method, and obtained samples of 18 companies.

\subsection{Variable Operational Definitions}


Dependent variables in this study are the availability of environmental information that will be described as follows:

Availability of environmental information means providing data. Environmental information can be a useful tool in assessing and determining problem priorities and making recommendations for policymaking and planning to assist local governments in environmental management and implementing sustainable development mandates. The approach to calculating the level of environmental disclosure using a dichotomy approach is that each environmental disclosure item is rated 1 when disclosed and a value of 0 if not declared. The formula for calculating environmental information is as follows [10]:

$$
\mathrm{IP}_{\mathrm{j}}=\frac{\Sigma \mathrm{X} i j}{n j}
$$

Description:

$\mathrm{IPj}=$ Disclosure of corporate environment $\mathrm{j}$

$\Sigma \mathrm{Xij}=$ number of items disclosed by the company $\mathrm{j}$

$\mathrm{nj}=$ number of items for company $\mathrm{j}, \mathrm{nj}<13$

The Independent variables in this study are Company Size, Company Performance, and Disclosure of media exposure that will be described as follows:

\section{.a. Company Size}

A company's size is a picture of the size or smallness of the company as determined through the natural logarithm of total assets. According to Jogiyanto [5], company size can be calculated with the following equation:

\section{Company Size $=$ Total Assets}

\section{b. Company Performance}

The company's performance variables in this study were measured by return On Asset (ROA). Roa ratio can be calculated as follows [11]:

$$
\text { Return OnAsset }(\text { ROA })=\frac{\text { Net Income }}{\text { Total Assets }} \times 100 \%
$$

\section{c. Disclosure of Media Exposure}

Variable media exposure is measured by dummy variables that are category 1 when there is news while category 0 when there is no news about the company's activities towards the environment.
Multiple regression models, according to Aulia and Agustina [8], are shown as follows:

$I P=\alpha+\beta_{1} \mathrm{ASSET}+\beta_{2} \mathrm{ROA}+\beta_{3} \mathrm{MEDIA}+\varepsilon$

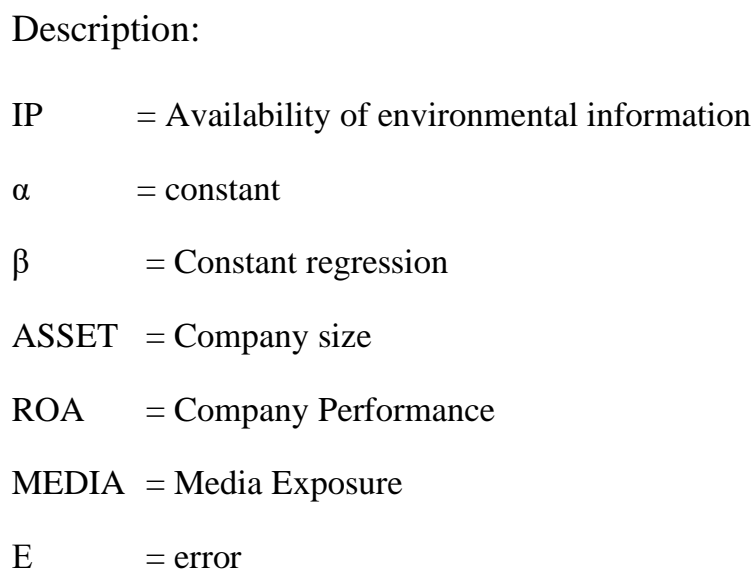

\section{RESULTS AND DISCUSSION}

\subsection{Descriptive Analysis}

Table 1: Descriptive Analysis

\begin{tabular}{|l|r|r|r|r|r|}
\hline & $\mathrm{N}$ & Min & Max & Mean & $\begin{array}{c}\text { Std. } \\
\text { Deviation }\end{array}$ \\
\hline company size & 54 & 20.90 & 32.20 & $\begin{array}{r}27.82 \\
06\end{array}$ & 2.43730 \\
\hline $\begin{array}{l}\text { company } \\
\text { performance }\end{array}$ & 47 & .00 & .53 & .1130 & .12158 \\
\hline $\begin{array}{l}\text { media } \\
\text { exposure }\end{array}$ & 54 & 0 & 24 & 7.17 & 6.049 \\
\hline $\begin{array}{l}\text { availability of } \\
\text { environmental } \\
\text { information }\end{array}$ & 54 & .08 & .69 & .3769 & .16826 \\
\hline $\begin{array}{l}\text { Valid N (listwise) } \\
\text { Source: output spss } 25\end{array}$ & 47 & & & & \\
\hline
\end{tabular}

Descriptive statistical test results, namely Size Variable, have a minimum value of 20.90, a maximum value of 32.20 , a mean value of 27.8206 , and a standard deviation value of 2.43730 . The Company's Performance Variable has a minimum value of 0.00 , a maximum value of 0.53 , a mean value of .1130, and a standard deviation value of .12158. The media Exposure variable has a 
minimum value of 0 , a maximum value of 24 , a mean value of 7.17 , and the standard deviation value of 6.049. Environment Information Availability variable has a minimum value of .08 maximum value of .69 with mean value of .3769 and value standard deviation of .16826.

\subsection{Analysis of Multiple Linear Regression}

The influence of variable company size, company performance, and media exposure on the availability of environmental information in food and beverages sector companies listed in the IDX in 2016-2018 is $29.3 \%$, while other variables outside this study influence the remaining $70.7 \%$. For example, profitability, industry type, environmental performance, company life, and stake holders power.

Variable company size, company performance, and media exposure simultaneously affect environmental information availability. The three dependent variables are included in the regression equation model is only one variable that affects the availability of environmental information, namely media exposure.

Table 2: Multiple Linear Regression Analysis

\begin{tabular}{|c|c|c|c|c|c|c|}
\hline & & \multicolumn{2}{|c|}{$\begin{array}{c}\text { Unstandardized } \\
\text { Coefficients }\end{array}$} & \multirow{2}{*}{$\begin{array}{c}\text { Standardized } \\
\text { Coefficients } \\
\text { Beta } \\
\end{array}$} & \multirow[b]{2}{*}{$\mathrm{t}$} & \multirow[b]{2}{*}{ Sig. } \\
\hline \multicolumn{2}{|c|}{ Model } & B & $\begin{array}{l}\text { Std. } \\
\text { Error }\end{array}$ & & & \\
\hline \multirow[t]{4}{*}{1} & (Constant) & .265 & .342 & & .776 & .442 \\
\hline & company size & .000 & .013 & .003 & .021 & .983 \\
\hline & $\begin{array}{l}\text { company } \\
\text { performance }\end{array}$ & -.104 & .190 & -.070 & -.546 & .588 \\
\hline & $\begin{array}{l}\text { media } \\
\text { exposure }\end{array}$ & .016 & .004 & .566 & 3.598 & .001 \\
\hline \multicolumn{2}{|l|}{$\mathrm{F}$} & \multicolumn{5}{|l|}{7.368} \\
\hline \multicolumn{2}{|c|}{ Sig. } & \multicolumn{5}{|l|}{$.000^{\mathrm{a}}$} \\
\hline \multicolumn{2}{|c|}{ Adjusted R Square } & \multicolumn{5}{|l|}{.293} \\
\hline
\end{tabular}

a. Dependent Variable: availability of environmental information

Source : output spss 25

\subsection{The Effect of Company Size on The Availability of Environmental Information}

Based on the tests that have been done, the study's findings indicate that the variable of company's size do not influence environmental information availability. This can be seen from a significant gain of 0.983 with a coefficient of 0.021 . A significant value indicates $0.983>0.05$, thus $\mathrm{H} 1$ is rejected. This suggests that the size of the company does not necessarily provide a lot of information about the environment because the company tends to maintain an image of a valuable company in the eyes of investors or other external parties. The size of a company will equally strive to maintain a company's value by minimizing the impact of environmental risks that exist in the annual report. Therefore the company will disclose environmental information voluntarily. Investors and external parties are more interested in financial information than corporate environmental information disclosed by the company.

This is in line with Zaenuddin [12] research, which stated that the large size of the company would increase the tendency of social and environmental disclosure in a non-significant way, the larger company will tend to cover the social and environmental impacts to keep the company's value.

Compared to the research conducted by [6], the size of the company is the scale that defines the size or company's size. Large companies assessed with large levels of assets will reveal more environmental responsibilities carried out by the company. The bigger the scale of the company, the greater the environmental impact. To maintain its legitimacy, the company will make more disclosures as a responsibility to the community.

\subsection{The Effect of The Company's Performance on the Availability of Environmental Information}

Based on the tests that have been done, it is indicated that the variable of company's performance does not influence environmental information availability. This can be seen from a significant gain of 0.588 with a coefficient of -0.546 . A significant value indicates $0.588>0.05$ so that it can be concluded $\mathrm{H} 2$ is rejected. Companies with good company performance tend not to disclose environmental information because they have obtained a positive image of a company both internally and externally. Therefore investors and other external parties view the company's performance in generating profit rather than disclosing environmental information carried out by the company.

Companies that have optimal performance do not have to disclose detailed environmental information because the company's performance in generating profits comes not only from the presentation of 
environmental information but through the net profit of sales and the use of assets.

This is not consistent with the analysis carried out by [6]. The Company's performance is part of environmental performance, companies that have optimal performance in terms of the corporate environment tend to reveal environmental information. It is done as an effort to distinguish yourself from companies that have low environmental performance. Good environmentalists believe that disclosing environmental performance will provide an advantage for the company.

\subsection{The Effect of Media Exposure on The Availability of Environmental Information}

Based on the tests that have been done, the results of this study show that variable media exposure affects environmental information availability. This can be seen from a significant gain of 0.001 with a coefficient of 3.598. A significant value indicates $0.001<0.05$ so that it can be concluded H3 is accepted. This is because media exposure is substantial for the public and other stakeholders as shareholders to assess the company's performance, which refers to the issues issued by media coverage versus the company's financial side. This makes the company move through media exposure to meet the needs of information for the community.

For companies that want to gain trust and legitimacy through their social and environmental activities, they must have the capacity to address the needs of stakeholders and to interact efficiently with their stakeholders. This is in accordance with the study carried out by [8]. Media exposure in this research represents the community and other stakeholders as nonshareholders. Nonshareholders rated the company's performance as based on media coverage issues compared to the company's financial side. The existence of media coverage shows that the public has information about the company's environmental issues. It makes the company react by creating a broader environmental disclosure to meet the needs of information for the community.

\section{CONCLUSIONS}

Based on the interpretation of the data in this research, the company's size variables do not affect the availability of environmental information. The company's performance variables have no impact on the availability of environmental information. And the variable disclosure of media exposure has shown a significant influence towards the availability of environmental information.

In this study, there are still limitations in using data analysis used is still not maximal. For improvement, the researchers are then expected to develop with better findings or innovations.

Analysis on the effects of company size, company performance, and media exposure on the availability of environmental information is not yet perfect.

1. It is expected that there will be research that discusses the availability of this environmental information by adding other variables such as profitability, industry type, environmental performance, company life, and stakeholders' power.

2. This research period is only limited to three years, namely in 2016-2018 should be for further research to increase the period of research years to be more varied.

\section{ACKNOWLEDGMENTS}

Based on the data analysis in this study, the company's size variables do not affect the availability of environmental information. The company's performance variables have no impact on the availability of environmental information. And the variable disclosure of media exposure has a significant effect on the availability of environmental information.

\section{REFERENCES}

[1] Ikatan Akuntansi Indonesia (IAI). 2019. Pernyataan Standar Akuntansi Keuangan (PSAK), Jakarta: IAI

[2] Undang-Undang Nomor 25 Tahun 2007 Tentang Penanaman Modal.

[3] Ghomi \& Leung, 2013. An Empirical Analysis of The Determinants of Greenhouse Gas Voluntary Disclosure in Australia. Accounting and Finance Research, 2 (1)

[4] Ghozali, I dan Chariri, A. 2007. Teori Akuntansi. Semarang: Badan Penerbit Undip.

[5] Jogiyanto. 2017. Teori Portofolio dan Analisis Investasi. Yogyakarta: BPFE-Yogyakarta.

[6] Dewi, Ida Ayu Putu Oki Yacintya dan Yasa, Gerianta Wirawan. 2017. "Pengaruh Ukuran Perusahaan, Profitabilitas, Tipe Industri dan Kinerja Lingkungan Terhadap Environmental Disclosure". E-Jurnal Akuntansi Universitas Udayana. 
[7] Halim, Abdul dan Mamduh M. Hanafi. 2009. Analisis Laporan Keuangan. Edisi 4. UPP STIM YKPN. Yogyakarta.

[8] Aulia, Febri Z dan Agustina, Linda. (2015). "Pengaruh Karakteristik Perusahaan, Kinerja Lingkungan dan Liputan Media Terhadap Environmental Disclosure". Accounting Analysis Journal. 4(3).

[9] www.idx.co.id

[10] Peraturan Bapepam Nomor VIII.G.2didownload dari www.bapepam.go.id

[11] Ikatan Bankir Indonesia. 2015. Manajemen Resiko 2. Jakarta: Gramedia Pustaka Utama.

[12] Zaenuddin, A. 2007. Faktor-Faktor Yang Berpengaruh Terhadap Praktek Pengungkapan Sosial Dan Lingkungan Pada Perusahaan Manufaktur Go Publik. Thesis. Universitas Diponegoro, Semarang. 